\title{
Impact of tillage system on arbuscular mycorrhiza fungal communities in the soil under Mediterranean conditions
}

\author{
Isabel Brito ${ }^{\mathrm{a}, *}$, Michael J. Goss ${ }^{\mathrm{b}}$, Mário de Carvalho ${ }^{\mathrm{a}}$, Odile Chatagnier ${ }^{\mathrm{c}}$, Diederik van Tuinen $^{\mathrm{c}}$ \\ a Universidade de Évora - ICAAM, Apartado 94, 7002 - 554 Évora, Portugal \\ ${ }^{\mathrm{b}}$ Kemptville Campus, University of Guelph, Kemptville, Ontario KOG 1J0, Canada \\ ' UMR INRA 1084, CNRS 5184, Université de Bourgogne, PME INRA CMSE, BP 86510, 21065 Dijon Cedex, France
}

\section{A R T I C L E I N F O}

\section{Article history:}

Received 25 October 2011

Received in revised form 17 January 2012

Accepted 19 January 2012

\section{Keywords:}

Arbuscular mycorrhiza (AM) fungi

Genetic diversity

Soil tillage

Large ribosomal subunit (LSU rDNA)

\begin{abstract}
A B S T R A C T
A more diverse arbuscular mycorrhiza (AM) fungal community should be more versatile and resilient to variation in environmental conditions over space and time. To evaluate the effect of no-till and conventional tillage systems, AM fungal diversity was assessed as part of a long term field experiment by sequencing of DNA, extracted from soil, that encoded the large ribosomal sub-unit and was obtained by nested-PCR. In comparison with no-till, conventional tillage decreased AM fungal diversity by $40 \%$. Differences between treatments in the frequency of the operational taxonomic units (OTUs) present in soil, confirm that AM fungi are differently vulnerable to soil disturbance.
\end{abstract}

(c) 2012 Elsevier B.V. All rights reserved.

\section{Introduction}

Arbuscular mycorrhiza fungi (AMF) exhibit considerable functional diversity, at the inter- and intraspecific level (Koide, 2000; Munkvold et al., 2004). There are pronounced plant $\times$ fungus interactions (Klironomos et al., 2001; Pivato et al., 2007) together with seasonal variability (Allen et al., 1995; Daniell et al., 2001) and evidence of many synergistic and complementary effects between fungal species that occur together (van Tuinen et al., 1998; Gustafson and Casper, 2006; Jansa et al., 2008). Consequently, diversity among AMF has practical implications for the quantitative outcome of specific symbioses. Depending on the prevailing environmental conditions, a diverse community of AMF would be expected to increase the frequency of successful symbioses.

Douds and Millner (1999) argued that an understanding of the impacts of agronomic practices on communities of AMF would help the development of approaches to ensure the establishment of a symbiosis and contribute to the identification and success of sustainable management options. Any factor causing differential reproduction and survival of AMF would operate as a selective pressure on the composition of the soil population and have consequences for the dynamics and diversity of the fungal community. Therefore knowledge of the different factors influencing the population of AMF has been viewed as essential in any

\footnotetext{
* Corresponding author. Tel.: +351 266760 800; fax: +351266 760914 .

E-mail address: ibrito@uevora.pt (I. Brito).
}

attempt to use them in sustainable agriculture (Bethlenfalvay and Linderman, 1992).

Soil disturbance is one factor which, through disrupting the extraradical mycelium (Jasper et al., 1989; Evans and Miller, 1990) and mixing surface residues into the soil profile (Abbott and Robson, 1991; Kabir et al., 1998), selectively interferes with different AMF, depending on their life and colonising strategies, promoting or impairing specific groups (Abbott et al., 1992; Brundrett et al., 1999; Klironomos and Hart, 2002). Glomus spp. are believed to survive perturbations well and hence prevail in highly disturbed agricultural systems (Douds et al., 1995; Dodd et al., 2000). It seems likely that AMF that depend mainly on extraradical mycelium to colonise roots of newly sown plants would be more frequent in no-till systems whereas those relying mostly on spores for colonisation would be less affected by soil disturbance. However, evidence from the literature suggests that this is too simplistic. For example, Jansa et al. (2003) proposed that changes in the community structure (abundance and diversity) of AMF, which colonised maize roots, could result from differences between species of AM fungi in their tolerance to the tillage-induced disruption of the hyphae together with changes in the nutrient content of the soil, the activity of other microbes and changes in weed populations. Nevertheless, a reduction in the diversity of $\mathrm{AM}$ fungal communities in roots from distinct agro-ecosystems specifically imposed by conventional tillage has been reported by several studies (Schnoor et al., 2011; Alguacil et al., 2008).

For studies of the diversity of AMF the choice of using soil (Cesaro et al., 2008) or root samples (Clapp et al., 1995; van Tuinen et al., 1998; Gollotte et al., 2004) as the basis of investigation is 
Table 1

Essential chemical characteristics of the soil from the field experiment.

\begin{tabular}{|c|c|c|c|c|c|}
\hline Field plot & Soil layer $(\mathrm{cm})$ & $\mathrm{P}_{2} \mathrm{O}_{5}\left(\mathrm{mg} \mathrm{kg}^{-1}\right)$ & $\mathrm{K}_{2} \mathrm{O}\left(\mathrm{mg} \mathrm{kg}^{-1}\right)$ & pH (water) & $\mathrm{OM}\left(\mathrm{mg} \mathrm{g}^{-1}\right)$ \\
\hline \multirow[t]{2}{*}{ No-till } & $0-10$ & 59 & 83 & 5.3 & 16 \\
\hline & $10-20$ & 25 & 59 & 5.7 & 9 \\
\hline \multirow[t]{2}{*}{ Conv. tillage } & $0-10$ & 19 & 59 & 5.6 & 10 \\
\hline & $10-20$ & 16 & 63 & 5.6 & 10 \\
\hline
\end{tabular}

important because of the possibility that biological bias introduced by the host plant will influence the taxonomic groups present in the roots (Jansa et al., 2002) or their abundance (Pivato et al., 2007). Moreover, to identify AM fungal diversity based on soil analysis has the advantage that all forms of inoculum (spores, extraradical mycelium and colonised root fragments) are likely to be present in the samples, immediate biological bias is avoided and species identification is less dependent on spore formation.

The annual contrast in the soil environment associated with the Mediterranean climate might cause a diverse AM fungal community to be an important factor in the resilience of agricultural systems and possible performance of crops. We hypothesise that in the longer term crop production using no-till will enhance soil AM fungal diversity compared with conventional tillage. To evaluate the effect of the tillage system on the soil AM fungal community structure under Mediterranean conditions, an approach based on nested PCR was applied to soil samples from a long term study of no-till and conventional tillage systems, conducted in the Alentejo Province of southern Portugal.

\section{Materials and methods}

AMF propagules, mycelium, colonised root fragments and spores, and spore densities are known to exhibit a strong spatial structuring at small scales (Bever et al., 2001; Wolfe et al., 2007). Consequently, designing sampling procedures for evaluating diversity, when AMF distribution is spatially heterogeneous, is a complex problem. The results of Whitcomb and Stutz (2007) clearly indicate that sampling intensity and strategy can affect perceptions of AMF community structure. However in an agricultural field the patchy distribution is reduced, in part, as the same host plant is dominant across a field and the pattern of cropping rows helps to determine the location of plant roots.

The study was conducted under field conditions at the Revilheira farm, Alentejo $\left(38^{\circ} 28^{\prime} \mathrm{N} 7^{\circ} 28^{\prime} \mathrm{W}\right)$. This site has been used since 1995 as part of a large research program on soil tillage with different crop rotations. Two tillage systems were compared: conventional tillage (mouldboard plough followed by a disk harrow) (CT) and no-till, direct seeding (NT). The rotation was wheat-triticale-sunflower. The soil was a Luvissol and the chemical characteristics of the $0-10 \mathrm{~cm}$ and $10-20 \mathrm{~cm}$ soil layers for the two tillage treatments are given in Table 1.

\subsection{Sampling procedure}

Soil samples were taken in the wheat field after harvest in June 2004. Two adjacent tillage plots were selected to reduce soil (physical and chemical characteristics) and field (slope, shade) variability. One plot had been cultivated by conventional tillage (mouldboard ploughed and then disk harrowed to form the seedbed) and was designated as the disturbed (D) treatment. The other plot, which had not been tilled for the last 9 years, was identified as the undisturbed (U) treatment. From each plot $(6 \times 17 \mathrm{~m}), 10$ soil cores of approximately $200 \mathrm{~mL}(0-10 \mathrm{~cm})$ were taken at random across the plot and then mixed to produce a single composite sample. This soil was sieved and very carefully homogenised and a sample was kept at $4{ }^{\circ} \mathrm{C}$ until used.

\subsection{Laboratory procedures for OTUs definition}

Three $200 \mathrm{mg}$ sub-samples of the composite sample from each field plot were used to isolate total DNA according to MartinLaurent et al. (2001). Next, $1 \mu \mathrm{L}$ of the purified DNA and a 1/10 dilution was used to perform the first PCR amplification with the eukaryotic specific primers LR1 and NDL22 (van Tuinen et al., 1998) designed to border the D1 and D2 variable domains of the $5^{\prime}$ end of the large ribosomal subunit encoding gene. Reactions were performed in a final volume of $20 \mu \mathrm{L}$ containing $2 \mu \mathrm{L} 10 \times$ PCR buffer with $1.5 \mathrm{mM} \mathrm{MgCl}_{2}$ (Qbiogen), $2.5 \mathrm{mM}$ dNTP, $10 \mu \mathrm{M}$ of each primer, $0.5 \mathrm{U}$ per $100 \mu \mathrm{L}$ of Taq polymerase (Qbiogen) and an aliquot $(1 \mu \mathrm{L})$ of soil DNA in ultra-pure water all overlaid with mineral oil. Amplification was performed in a thermal cycler (Biometra T3000) programmed as follows: initial denaturation cycle at $93{ }^{\circ} \mathrm{C}(3 \mathrm{~min})$, annealing at $56{ }^{\circ} \mathrm{C}(1 \mathrm{~min})$, extension at $72{ }^{\circ} \mathrm{C}$ ( $1 \mathrm{~min}$ ) followed by 29 cycles of denaturation at $93^{\circ} \mathrm{C}(1 \mathrm{~min})$, annealing at $56{ }^{\circ} \mathrm{C}(1 \mathrm{~min})$ and extension at $72{ }^{\circ} \mathrm{C}(1 \mathrm{~min})$. The last cycle was followed by a final extension at $72{ }^{\circ} \mathrm{C}$ for $5 \mathrm{~min}$. For this PCR $1 \mu \mathrm{L} /$ reaction of the T4 bacteriophage gene 32 product (T4 gp 32) (Q-Bio Gene) was added.

The amplification product was diluted $1 / 500$ and used as template for the second PCR with the primers LR1 and the AMF specific primer FRL4 (Gollotte et al., 2004). The PCR conditions were similar except that the number of cycles was 28 and the annealing temperature was $60{ }^{\circ} \mathrm{C}$.

The second PCR products were separated on a $1.4 \%$ agarose gel in TAE buffer ( $40 \mathrm{mM}$ Tris, pH 7.8, $20 \mathrm{mM}$ acetic acid and $2 \mathrm{mM}$ EDTA) and visualised under UV light after ethidium bromide staining $\left(50 \mu \mathrm{g} \mathrm{L}^{-1}\right)$.

The product of the second PCR was pooled together and cloned using a TOPO TA Cloning ${ }^{\mathbb{R}}$ kit for sequencing (ref. 45-0030 or 450641, Invitrogen). The selection of clones to be analysed further was made according to the number of base pairs in the second PCR product, using only inserts ranging between 650 and $750 \mathrm{bp}$; the expected size for AMF. As a result 48 positive clones (white colonies) were analysed by PCR, using the LR1-FLR4 primers. These clones were multiplied in liquid LB medium (ref. 12780-052 Invitrogen $)$ with ampicillin $\left(0.5 \mu \mathrm{g} \mathrm{mL}^{-1}\right)$ and the plasmid purified using kit (Nucleo Spin ${ }^{\circledR}$ Plasmid, Macherey-Nagel). The plasmids were sent for sequencing by MWG (Germany).

All sequences were checked through a BLASTN analysis (Altschul et al., 1997) for the presence of chimeric sequences, generated during this procedure, and then aligned with ClustalW. Only four chimeric clones were detected and withdrawn from the analysis.

The sequences were aligned with MAFFT and the alignment was optimised manually using the Se-Al v 2.0 software (University Oxford). Phylogenetic analyses were performed using the neighbour joining ( $\mathrm{NJ}$ ) algorithm included in the ClustalW program, using Mortierella multidivaricata as an out-group. Positions with gaps were ignored and the reliability of the internal branches of the NJ tree was assessed using the bootstrap method with 1000 replicates. Tree files were drawn using njplot (http://biom3.univ-lyon1.fr) and the sequences grouped together in OTUs on the bootstrap values, with a threshold of more than 970\%. 


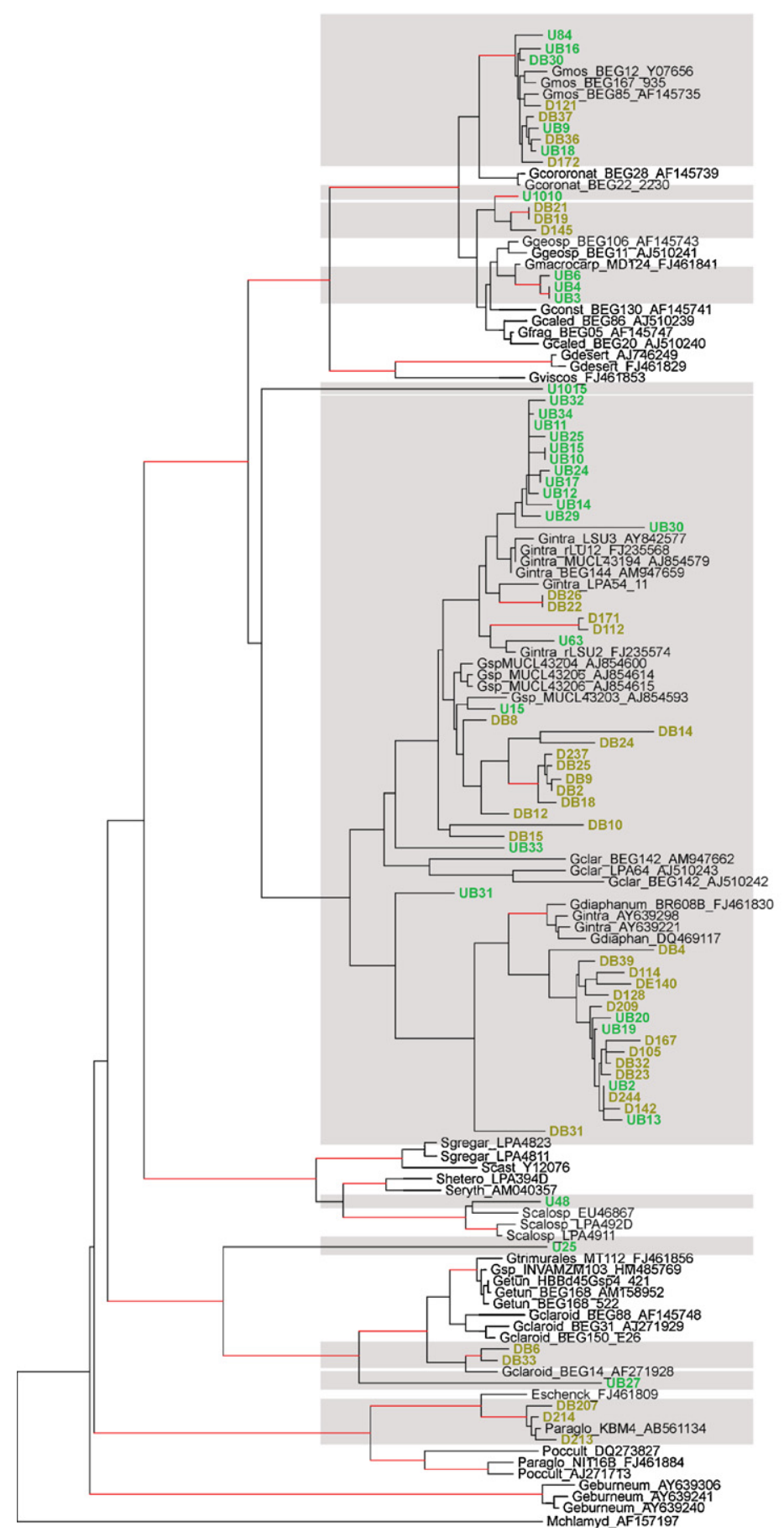

\subsection{2}

G. mosseae

Glomus I

Glomus II

Glomus III

Glomus IV

G irregulare

Scutellospora I

Glomus V

G. claroieum-etunicatum Glomus VI

Paraglomus

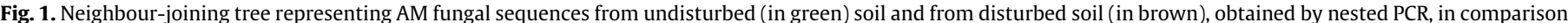

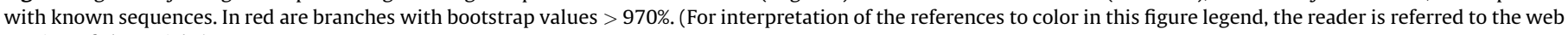
version of the article.)

Rarefaction curves were constructed with the freeware program Analytical Rarefaction 1.3 (www.uga.edu strata/software) to determine whether the number of sequences tested sufficiently represents Glomeromycota diversity in the studied soils (Fig. 3). An ANOVA was preformed to compare the two rarefaction curves using MSTAT-C (version 1.42, Michigan State University) statistical package (Table 2).

\section{Results}

Using the results from both analyses a total of 83 sequences of good quality were obtained, 36 from the undisturbed treatment and 47 from the disturbed soil Fig. 1. The number of operational taxonomic units (OTUs) in the different clusters is reported in Fig. 2. With the exception of one ribotype, identified as a Scutellospora, all the other OTUs belonged to the Glomineae, and mainly to Glomaceae. Four OTUs could be identified at the species level, namely Glomus mosseae, G. irregulare, G. claroideum-etunicatum and G. occultum basionym of Paraglomus occultum. According to the data obtained only two of the OTUs found (G. mosseae, G. irregulare) were present in both soil types, six could only be found in undisturbed soil and three only in disturbed soil. The AM fungal diversity was higher in undisturbed soil, where eight different OTUs were identified, 


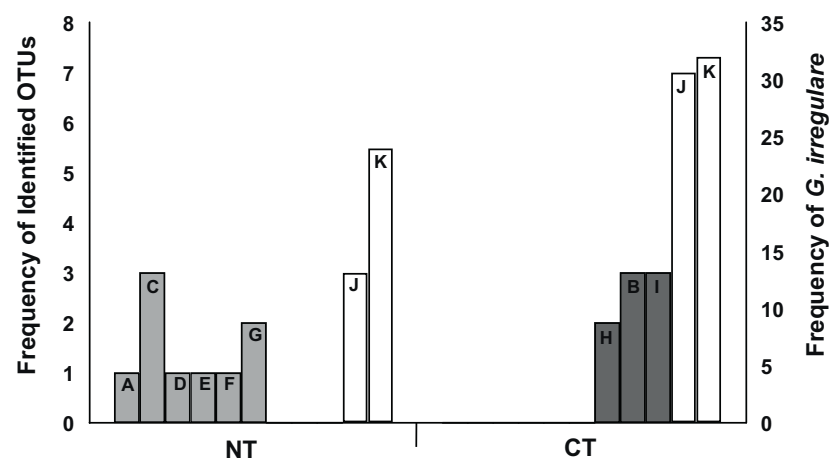

Fig. 2. Identified operational taxonomic units (OTUs) in the two tillage treatments (A - Glomus I; B - Glomus II; C - Glomus III; D - Glomus IV; E - Glomus V; F Glomus VI; G - Scutellospora; H - G. cloroidium; I - G. ocultum; J - G. mosseae; K - G. irregulare). Light grey columns - OTUs found only in the no-tillage treatment; dark grey columns - OTUs found only in the conventional tillage treatment; white columns - OTUs found in both tillage treatments.

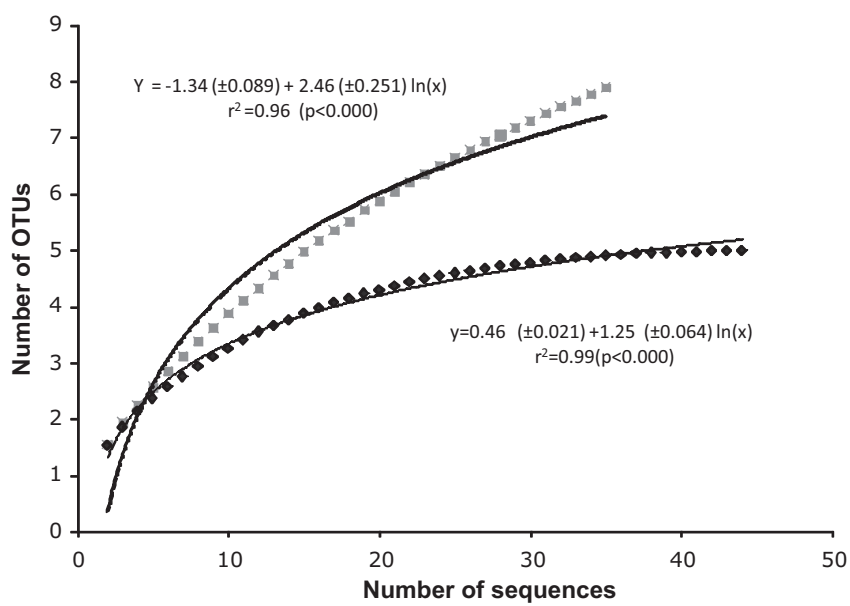

Fig. 3. Rarefaction curve including the data of both years and all the ribotypes identified in no-tillage (grey) and conventional tillage (black) treatments.

when compared to disturbed soil with only five OTUs recognised.

In the rarefaction curves the number of sequences analysed were plotted against the cumulative number of OTUs (Fig. 3), and the differences between the two equations were highly significant $(p<0.0001)$ as presented in Table 2. Despite the fact that most of the OTUs groups exclusively detected in no-till (Glomus I, IV, V and VI) are poorly represented (Fig. 2), the number of analysed sequences was larger than the one suggested by Pivato et al. (2007) as adequate for characterisation of the diversity of AMF in soil. Moreover, the rarefaction curves indicate that for conventional tillage the plateau had been reached. Consequently, if more

Table 2

Analyses of variance to compare the differences between the two equations of the rarefaction curves presented in Fig. 3.

\begin{tabular}{lrlll}
\hline Source & DF & Mean square & $F$ value & Prob. \\
\hline Between equations & 2 & 32.040 & 468.81 & $<0.0001$ \\
Differences in level & 1 & 48.016 & 172.22 & $<0.0001$ \\
Error & 76 & 21.190 & & \\
Differences in angle & 1 & 16.064 & 235.05 & $<0.0001$ \\
Error & 75 & 5.126 & & \\
\hline
\end{tabular}

sequences were analysed the diversity of AMF would only show an increase for no-till. Therefore, we consider that the data presented support the hypothesis that the diversity of AMF was greater under no-till.

\section{Discussion}

Blast searches in the GeneBank database showed that all sequences obtained in this study belonged to the Glomeromycota, confirming the specificity of the LR1-FLR4 primer pair for detection of Glomeromycota. The detection of Scutellospora and Paraglomus, confirmed that all the Glomeromycota families are amplified (Mummey and Rillig, 2007). Of the 83 sequences analysed, 36 were from undisturbed soil and 47 were from disturbed soil, each of which exceeds the minimum number of 30-35 identified by Pivato et al. (2007) as being required to describe the diversity of AMF in a field experiment and also greater than the number of sequences analysed by Schnoor et al. (2011). Differences between treatments in the frequency of the OTUs present in soil confirm that AMF are differently vulnerable to soil disturbance. This appears to be true, both in terms of the community structure, as the same OTUs show different frequencies depending on the level of soil disturbance, and in terms of diversity, given that the OTUs present in the undisturbed soil were not always the same as those isolated from disturbed soil (Fig. 2).

Under both experimental treatments, the OTU corresponding to cluster that included the ubiquitous $G$. irregulare, was clearly the most abundant found relative to other isolates from the Glomaceae. OTU within this taxonomic group provide evidence of high molecular diversity. Our findings are consistent with those of Mathimaran et al. (2005), who found that spores of G. irregulare were dominant in a soil community associated with wheat as host plant.

Diversity of the OTUs found under no-till was greater than that in disturbed soil, consistent with the view that species richness can be reduced by intensive tillage (Jansa et al., 2003; Alguacil et al., 2008; Schnoor et al., 2011). Although the frequency of some OTUs found in our study was small, this might be due to the use of soil instead of root samples. Pivato et al. (2007), studying the OTUs frequency in soil and roots, found significantly more present in root samples. Our results demonstrate an effect of tillage on the AMF community in soil irrespective of the host plant. Under mixed farming systems or crop rotation the enhanced diversity of AMF in soil could provide an advantage. An interesting investigation from an agronomic perspective would be to analyse the effect of tillage on the AM fungal community structure using mixed or sequential (crop rotation) host crops.

Belowground diversity is an essential component of ecosystem health (Bever et al., 2001) More diverse AMF communities would be able to exhibit greater versatility and resilience in response to variation of environmental conditions over space and time. By favouring diversity of AMF, management practices, such as no-till, have the possibility of encouraging mycorrhiza as the possible combinations of host plant and AMF are greater and, depending on eventual biotic or abiotic stresses, the chances of having a functional symbiosis are greater.

\section{Conclusion}

This study confirms that the use of soil samples is an appropriate tool to investigate the effect of production techniques on AMF biodiversity. The enhanced diversity observed under notill suggests that this tillage system has the potential to enhance the sustainable arable production systems. Our results validate the use of a minimum of 35 sequences to characterise AMF diversity under arable cropping systems. 


\section{References}

Abbott, L.K., Robson, A.D., 1991. Field management of VA mycorrhizal fungi. In: Keister, D.L., Cregan, P.B. (Eds.), The Rhizosphere and Plant Growth. Kluwer Academic Publishers, Netherlands, pp. 355-362.

Abbott, L.K., Robson, A.D., Gazey, C., 1992. Selection of inoculant vesicular-arbuscular mycorrhizal fungi. In: Norris, J.R., Read, D.J., Varma, A.K. (Eds.), Methods in Microbiology, vol. 24. Academic, London, pp. 1-21.

Alguacil, M.M., Lumini, E., Roldan, A., Salinas-García, J.R., Bonfante, P., Bianciotto, V., 2008. The impact of tillage practices on arbuscular mycorrhizal fungal diversity in subtropical crops. Ecol. Appl. 18, 527-536.

Allen, E.B., Allen, M.F., Helm, D.J., Trappe, J.M., Molina, R., Rincon, E., 1995. Patterns and regulation of mycorrhizal plant and fungal diversity. Plant Soil 170, 47-62.

Altschul, S.F., Madden, T.L., Schäffer, A.A., Zhang, J., 1997. Gapped BLAST and PSIBLAST: a new generation of protein database search programs. Nucleic Acids Res. 25, 3389-3402.

Bethlenfalvay, G.J., Linderman, R.G., 1992. Mycorrhizae in Sustainable Agriculture American Society of Agronomy, Special Publication, Madison.

Bever, J.D., Schultz, P.A., Pringle, A., Morton, J.B., 2001. Arbuscular mycorrhizal fungi: more diverse than meets the eye, and the ecological tale of why. Bioscience 51 923-931.

Brundrett, M.C., Abbott, L.K., Jasper, D.A., 1999. Glomalean fungi from tropical Australia. I. Comparison of the effectiveness of isolation procedures. Mycorrhiza 8, 305-314.

Cesaro, P., van Tuinen, D., Copetta, A., Chatagnier, O., Berta, G., Gianinazzi, S., Lingua, G., 2008. Preferential colonization of Solanum tuberosum L. roots by the fungus Glomus intraradices in arable soil of a potato farming area. Appl. Environ. Microbiol. 74, 5776-5783.

Clapp, J.P., Young, J.P.W., Merryweather, J.W., Fitter, A.H., 1995. Diversity of fungal symbionts in arbuscular mycorrhiza from a natural community. New Phytol. $130,259-265$.

Daniell, T.J., Husband, R., Fitter, A.H., Young, J.P.W., 2001. Molecular diversity of arbuscular mycorrhizal fungi colonising arable crops. FEMS Microbiol. Ecol. 36, 203-209.

Dodd, J.C., Boddington, C.L., Rodriguez, A., Gonzalez-Chavez, C., Mansur, I., 2000 Mycelium of arbuscular mycorrhizal fungi (AMF) from different genera: form, function and detection. Plant Soil 226, 131-151.

Douds Jr., D.D., Galvez, L., Janke, R.R., Wagoner, P., 1995. Effect of tillage and farming system upon populations and distribution of vesicular-arbuscular mycorrhizal fungi. Agr. Ecosys. Environ. 52, 111-118.

Douds Jr., D.D, Millner, P.A., 1999. Biodiversity of arbuscular mycorrhizal fungi in agroecosystems. Agr. Ecosys. Environ. 74, 77-93.

Evans, D.G., Miller, M.H., 1990. The role of the external mycelial network in the effect of soil disturbance upon vesicular-arbuscular mycorrhizal colonization of maize. New Phytol. 114, 65-71.

Gollotte, A., van Tuinen, D., Atkinson, D., 2004. Diversity of arbuscular mycorrhizal fungi colonising roots of the grass species Agrostis capillaris and Lolium perenne in a field experiment. Mycorrhiza 14, 111-117.

Gustafson, D.J., Casper, B.B., 2006. Differential host plant performance as a function of soil arbuscular mycorrhizal fungal communities: experimentally manipulating co-occurring Glomus species. Plant Ecol. 183, 257-263.
Jansa, J., Mozafar, A., Anken, T., Ruh, R., Sanders, I.R., Frossard, E., 2002. Diversity and structure of AMF communities as affected by tillage in a temperate soil. Mycorrhiza 12, 225-234.

Jansa, J., Mozafar, A., Kuhn, G., Anken, T., Ruh, R., Sanders, I.R., Frossard, E., 2003. Soil tillage affects the community structure of mycorrhizal fungi in maize roots. Ecol. Appl. 13, 1164-1176.

Jansa, J., Smith, F.A., Smith, S.E., 2008. Are there benefits of simultaneous root colonization by different arbuscular mycorrhizal fungi? New Phytol. 177, 779789.

Jasper, D.A., Abbott, L.K., Robson, A.D., 1989. Soil disturbance reduces the infectivity of external hyphae of vesicular- arbuscular mycorrhizal fungi. New Phytol. 112, 93-99.

Kabir, Z., O'Halloran, I.P., Widden, P., Hamel, C., 1998. Vertical distribution of arbuscular mycorrhizal fungi under corn (Zea mays L.) in no-till and conventional tillage systems. Mycorrhiza 8, 53-55.

Klironomos, J.N., Hart, M.M., 2002. Colonization of roots by arbuscular mycorrhizal fungi using different sources of inoculum. Mycorrhiza 12, 181-184.

Klironomos, J.N., Hart, M.M., Gurney, J.E., Moutoglis, P., 2001. Interspecific differences in the tolerance of arbuscular mycorrhizal fungi to freezing and drying. Can. J. Bot. 79, 1161-1166.

Koide, R.T., 2000. Functional complementarity in the arbuscular mycorrhizal symbiosis. New Phytol. 147, 233-235.

Martin-Laurent, F., Philippot, L., Hallet, S., Chaussod, R., Germon, J.C., Soulas, G., Catroux, G., 2001. DNA extraction from soils: old bias for new microbial diversity analysis methods. Appl. Environ. Microb. 67, 2354-2359.

Mathimaran, N., Ruh, R., Vullioud, P., Frossard, E., Jansa, J., 2005. Glomus intraradices dominates arbuscular mycorrhizal communities in a heavy textured agricultural soil. Mycorrhiza 16, 61-66.

Mummey, D.L., Rillig, M.C., 2007. Evaluation of LSU rRNA-gene PCR primers for the study of arbuscular mycorrhizal fungal communities via terminal restriction fragment length polymorphism analysis. J Microbiol Meth 70, 200-204.

Munkvold, L., Kjoller, R., Vestberg, M., Rosendahl, S., Jakobsen, I., 2004. High functional diversity within species of arbuscular mycorrhizal fungi. New Phytol. $164,357-364$

Pivato, B., Mazurier, S., Lemanceau, P., Siblot, S., Berta, G., Mougel, C., van Tuinen, D., 2007. Medicago species affect the community composition of arbuscular mycorrhizal fungi associated with roots. New Phytol. 176, 97-210.

Schnoor, T.K., Lekberg, Y., Rosendahl, S., Olsson, P.A., 2011. Mechanical soil disturbance as a determinant of arbuscular mycorrhizal fungal communities in seminatural grassland. Mycorrhiza 21, 211-220.

van Tuinen, D., Jacquot, E., Zhao, B., Gollotte, A., Gianinazzi-Pearson, V., 1998. Characterization of root colonization profiles by a microcosm community of arbuscular mycorrhizal fungi using 25S rDNA-targeted nested PCR. Mol. Ecol. 7, 879-887.

Whitcomb, S., Stutz, J.C., 2007. Assessing diversity of arbuscular mycorrhizal fungi in a local community: role of sampling effort and spatial heterogeneity. Mycorrhiza 17, 429-437.

Wolfe, B.E., Rillig, M.C., Mummey, D.L., Klironomos, J.N., 2007. Small-scale spatial heterogeneity of arbuscular mycorrhizal fungi in a calcareous fen. Mycorrhiza 17, 175-183. 